\title{
Article \\ Detection of Mycoplasma Contamination in Transplanted Retinal Cells by Rapid and Sensitive Polymerase Chain Reaction Test
}

\author{
Sunao Sugita ${ }^{1,2, *,+}$, Ayumi Hono ${ }^{1,+}$, Shoko Fujino ${ }^{1}$, Yoko Futatsugi ${ }^{1}$, Yuta Yunomae ${ }^{3,4}$, Norio Shimizu ${ }^{3}$ and \\ Masayo Takahashi ${ }^{1,2}$
}

1 RIKEN Center for Biosystems Dynamics Research, Laboratory for Retinal Regeneration, 2-2-3 Minatojima-minamimachi, Kobe 650-0047, Japan; ayumi.hono@riken.jp (A.H.); shoko.fujino@riken.jp (S.F.); yoko.futatsugi@riken.jp (Y.F.); retinalab@ml.riken.jp (M.T.)

2 Vision Care Inc., Kobe 650-0047, Japan

3 Center for Stem Cell and Regenerative Medicine, Tokyo Medical and Dental University, Tokyo 113-8510, Japan; y-yunomae@nissui-pharm.jp (Y.Y.); nshivir@tmd.ac.jp (N.S.)

4 Nissui Pharmaceutical Co., Ltd., Tokyo 110-8736, Japan

* Correspondence: sunao.sugita@riken.jp or sugita@vision-care.jp; Tel.: +81-78-306-3305; Fax: +81-78-306-3303

$\dagger$ These authors contributed equally to this work.

check for updates

Citation: Sugita, S.; Hono, A.; Fujino, S.; Futatsugi, Y.; Yunomae, Y.; Shimizu, N.; Takahashi, M. Detection of Mycoplasma Contamination in Transplanted Retinal Cells by Rapid and Sensitive Polymerase Chain Reaction Test. Int. J. Mol. Sci. 2021, 22, 12555. https://doi.org/10.3390/ ijms222212555

Academic Editor: Manuel Simões

Received: 27 October 2021

Accepted: 19 November 2021

Published: 21 November 2021

Publisher's Note: MDPI stays neutral with regard to jurisdictional claims in published maps and institutional affiliations.

Copyright: (c) 2021 by the authors. Licensee MDPI, Basel, Switzerland. This article is an open access article distributed under the terms and conditions of the Creative Commons Attribution (CC BY) license (https:/ / creativecommons.org/licenses/by/ $4.0 /)$.

\begin{abstract}
Contamination of cells/tissues by infectious pathogens (e.g., fungi, viruses, or bacteria, including mycoplasma) is a major problem in cell-based transplantation. In this study, we tested a polymerase chain reaction (PCR) method to provide rapid, simple, and sensitive detection of mycoplasma contamination in laboratory cultures for clinical use. This mycoplasma PCR system covers the Mycoplasma species (spp.) listed for testing in the 17th revision of the Japanese Pharmacopoeia, and we designed it for use in transplantable retinal cells. Here, we analyzed mycoplasma contamination in induced pluripotent stem cell (iPS cell)-derived transplantable retinal pigment epithelium (RPE) cells. In the spike tests to RPE cells with nine species of class Mollicutes bacteria, including seven Mycoplasma spp. and one of each Acholeplasma spp. and Ureaplasma spp., contamination at the concentration of 100 and $10 \mathrm{CFU} / \mathrm{mL}$ were detected with $100 \%$ probability in all cases, while $1 \mathrm{CFU} / \mathrm{mL}$ had a detection rate of $0-75 \%$. DNA prepared from bacteria species other than class Mollicutes species was not detectable, indicating the specificity of this PCR. While iPS cells and iPS-RPE cells established in our laboratory were all negative by this PCR, some of the commercially available cell lines were positive. Cells for transplantation should never have infection, as once pathogens are implanted into the eyes, they can cause severe intraocular inflammation. Thus, it is imperative to monitor for infections in the transplants, although generally, mycoplasma infection is difficult to detect.
\end{abstract}

Keywords: mycoplasma; polymerase chain reaction; iPS cells; retinal cells; clinical trial

\section{Introduction}

Induced pluripotent stem cells (iPS cells) can differentiate into several types of cells or tissues, and they are now used in clinical studies/trials. In our laboratory, we have been investigating human iPS cell-derived retinal pigment epithelium (RPE) cells, and we successfully transplanted iPS-RPE cell sheets into age-related macular degeneration patients in 2014 [1]. In 2017, a clinical study was conducted with allogeneic transplants rather than autologous transplants due to cost and other considerations, and HLA homozygote iPS-RPE cells were transplanted into five HLA-matched patients with age-related macular degeneration [2]. Although these clinical trials were successful and did not accompany any obvious problems, cell transplantation required the utmost care to avoid contamination of the transplants by pathogens, as transplanting infected cells into the eye could cause severe adverse events in patients. 
Generation of iPS cells and their differentiation into retinal cells, including RPE cells, require long-term culture (at least 8 months) with several passages, which demands consideration of possible contamination of cells with pathogenic microorganisms. Among them, the highest caution is required concerning infection by Mycoplasma species (spp.), as there is always a risk of transplanting mycoplasma-infected cells or tissues, which are hard to detect. In Japan, the 17th revision of the Japanese Pharmacopoeia defined the criteria for a mycoplasma contamination test. Conventional mycoplasma contamination tests, such as the culture method, DNA staining (by use of cultured Vero cells), and ELISA, have been used as standard tests. In addition, polymerase chain reaction (PCR) analysis (single-step, two-step nested PCR, or real-time PCR) is now being used. However, these examinations are time-consuming, especially for the culture method and the DNA staining method, and the procedures of PCR are often complicated [3-13]. Therefore, the purpose of this study was to examine whether rapid PCR could be applied to evaluate mycoplasma contamination in human iPS cell-derived transplantable RPE cells with the following criteria: (1) to serve as a comprehensive test of the genus Mycoplasma listed in the 17th Bureau Act, (2) to have high specificity and sensitivity, and (3) to be a rapid and simple procedure. In the present study, we applied a commercially available mycoplasma PCR system, the Myco Finder PCR, for validation on our transplantable RPE cells.

\section{Results}

\subsection{PCR Sensitivity in the Mycoplasma PCR Test}

First, we obtained the ratios of genomic copy (GC) number and colony-forming units (CFU) of the reference strains. For the assay, we used stocked strains of class Mollicutes including genus Mycoplasma (Mycoplasma arginini, Mycoplasma fermentans, Mycoplasma hyorhinis, Mycoplasma salivarium, Mycoplasma orale, Mycoplasma pneumoniae, and Mycoplasma hominis), genus Ureaplasma (Ureaplasma urealyticum), and genus Acholeplasma (Acholeplasma laidlawii). As a result, all tested strains demonstrated low GC/CFU ratios $(<100)$, which was less than $10(\mathrm{GC} / \mathrm{CFU}$ ratios $<10)$, except for M. pneumoniae (GC/CFU ratio $=30.59)$ (Table 1). Since the GC/CFU ratio is the ratio of the number of genomes against the number of live bacteria or fungal cells and the results for all strains were less than 100, this means for each strain, more than one live bacterium was present per 100 copies of the genome. When evaluating the sensitivity of mycoplasma tests based on nucleic acid amplification methods, 100 or less GC/CFU ratios of the reference product is desirable. Based on these results, we next examined the detection sensitivity of the Myco Finder PCR test.

Table 1. Summary of class Mollicutes reference strains with ratios of GC and CFU.

\begin{tabular}{ccccc}
\hline Mollicutes Species & Strains & CFU/mL & GC/mL * & GC/CFU Ratios \\
\hline Mycoplasma arginini & ATCC 23838 & $5 \times 10^{8}$ & $1.36 \times 10^{9}$ & 2.72 \\
Mycoplasma hyorhinis & NBRC 14858 & $8.83 \times 10^{8}$ & $1.9 \times 10^{9}$ & 2.15 \\
Mycoplasma pneumoniae & NBRC 14401 & $5.1 \times 10^{7}$ & $1.56 \times 10^{9}$ & 30.59 \\
Acholeplasma laidlawii & NBRC 14400 & $1.07 \times 10^{8}$ & $1.06 \times 10^{9}$ & 9.91 \\
Mycoplasma fermentans & NBRC 14854 & $1.04 \times 10^{9}$ & $3.76 \times 10^{9}$ & 3.62 \\
Mycoplasma salivarium & NBRC 14478 & $1.41 \times 10^{9}$ & $2.1 \times 10^{9}$ & 1.49 \\
Mycoplasma orale & NBRC 14477 & $6.37 \times 10^{8}$ & $2.32 \times 10^{9}$ & 3.64 \\
Mycoplasma hominis & NBRC 14850 & $4 \times 10^{7}$ & $1.76 \times 10^{9}$ & 4.55 \\
Ureaplasma urealyticum & ATCC 27618 & $2.03 \times 10^{8}$ & $7.2 \times 10^{8}$ & 3.54 \\
\hline
\end{tabular}

${ }^{*} \mathrm{GC} / \mathrm{mL}$ : genomic copies (GC)/mL.

For PCR sensitivity assays, the following strains were used: A. laidlawii, M. hyorhinis, $M$. pneumoniae, $M$. orale, $M$. fermentans, $M$. salivarium, $M$. arginini, $M$. hominis, and $U$. urealyticum. Table 2 shows the sensitivities of the PCR for the nine Mollicutes spp. In the spike test in human iPS-RPE cells, $100 \mathrm{CFU} / \mathrm{mL}$ were detected with $100 \%$ probability in all cases, and $10 \mathrm{CFU} / \mathrm{mL}$ were also detected with 100\% probability (Table 2). Surprisingly, spikes as low as $1 \mathrm{CFU} / \mathrm{mL}$ had a detection rate of $0-75 \%$, which means that some Mollicutes spp. were detected even with a few enough numbers to form a single colony. Of note, the 
class Mollicutes spp., besides Mycoplasma spp., Acholeplasma spp. (Acholeplasma laidlawii; NBRC14400), and Ureaplasma spp. (U. urealyticum; ATCC 27618), was also detectable by this Myco Finder PCR assay (Table 2). In the spike test in iPS-RPE cells, $100 \mathrm{CFU} / \mathrm{mL}$ was detected with $100 \%$ probability.

Table 2. Results of Mollicutes spp. PCR sensitivity test.

\begin{tabular}{|c|c|c|}
\hline A. laidlawii & & \\
\hline Spike (CFU/mL) & Run & Positive rate (\%) \\
\hline 100 & $4 / 4^{*}$ & 100 \\
\hline 10 & $4 / 4$ & 100 \\
\hline 1 & $1 / 4$ & 25 \\
\hline \multicolumn{3}{|l|}{ M. arginini } \\
\hline Spike (CFU /mL) & Run & Positive rate $(\%)$ \\
\hline 100 & $4 / 4$ & 100 \\
\hline 10 & $4 / 4$ & 100 \\
\hline 1 & $2 / 4$ & 50 \\
\hline \multicolumn{3}{|l|}{ M. hyorhinis } \\
\hline Spike (CFU/mL) & Run & Positive rate $(\%)$ \\
\hline 100 & $4 / 4$ & 100 \\
\hline 10 & $4 / 4$ & 100 \\
\hline 1 & $0 / 4$ & 0 \\
\hline \multicolumn{3}{|l|}{ M. pneumoniae } \\
\hline Spike (CFU/mL) & Run & Positive rate $(\%)$ \\
\hline 100 & $4 / 4$ & 100 \\
\hline 10 & $4 / 4$ & 100 \\
\hline 1 & $3 / 4$ & 75 \\
\hline \multicolumn{3}{|l|}{ M. orale } \\
\hline Spike (CFU/mL) & Run & Positive rate $(\%)$ \\
\hline 100 & $4 / 4$ & 100 \\
\hline 10 & $4 / 4$ & 100 \\
\hline 1 & $3 / 4$ & 75 \\
\hline \multicolumn{3}{|l|}{ M. fermentans } \\
\hline Spike (CFU/mL) & Run & Positive rate $(\%)$ \\
\hline 100 & $4 / 4$ & 100 \\
\hline 10 & $4 / 4$ & 100 \\
\hline 1 & $3 / 4$ & 75 \\
\hline \multicolumn{3}{|l|}{ M. salivarium } \\
\hline Spike (CFU/mL) & Run & Positive rate $(\%)$ \\
\hline 100 & $4 / 4$ & 100 \\
\hline 10 & $4 / 4$ & 100 \\
\hline 1 & $1 / 4$ & 25 \\
\hline \multicolumn{3}{|l|}{ M. hominis } \\
\hline Spike (CFU/mL) & Run & Positive rate $(\%)$ \\
\hline 100 & $4 / 4$ & 100 \\
\hline 10 & $4 / 4$ & 100 \\
\hline 1 & $4 / 4$ & 100 \\
\hline
\end{tabular}


Table 2. Cont.

\begin{tabular}{ccc}
\hline U. urealyticum & & \\
\hline Spike $(\mathrm{CFU} / \mathrm{mL})$ & Run & Positive rate $(\%)$ \\
100 & $4 / 4$ & 100 \\
10 & $1 / 4$ & 25 \\
1 & $0 / 4$ & 0 \\
\hline
\end{tabular}

${ }^{*} 4 / 4$ indicates that it was detected four times out of four PCR tests.

Representative PCR results of the mycoplasma sensitivity test are shown in Figure 1. In iPS-RPE cells spiked with $10 \mathrm{CFU} / \mathrm{mL}$ of M. arginini, the mycoplasma was detected in $100 \%$ of the trials (four times out of four trials; Table 2), and the spike at the concentration of $1 \mathrm{CFU} / \mathrm{mL}$ was detected with a probability of $50 \%$ (two times out of four trials; Table 2). The PCR cycle required for the detection correlated with the concentration of the spiked mycoplasma (Figure 1), indicating the detection could be semi-quantitative.

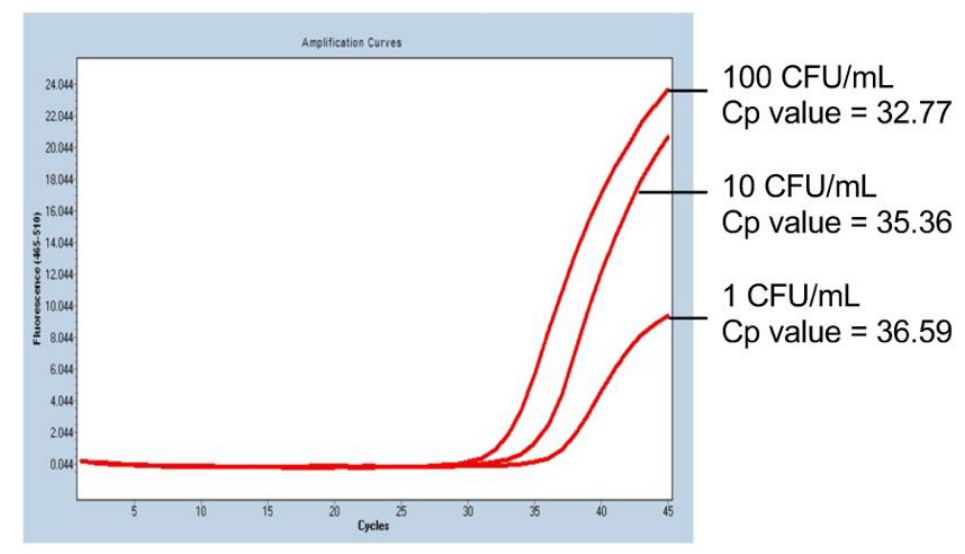

Figure 1. PCR results of the mycoplasma sensitivity test. In human iPS cell-derived RPE cells spiked with $M$. arginini, we observed that the number of PCR-cycles for the detection (red lines) depended on the concentration of the added M. arginini. Cp value: crossing point value.

\subsection{Specificity of the Mycoplasma PCR Test}

Next, the specificity of the mycoplasma PCR (Myco Finder) was verified by adding DNA from pathogens other than class Mollicutes species. For this assay, synthetic DNA of four bacteria other class Mollicutes, a fungus, and a virus were used. All six synthetic DNA templates, including those of bacterial species other than class Mollicutes, were not detected by this PCR (Figure 2A). Representative results of the specificity verification are presented in Figure 2B, which shows any of the examined DNA templates were undetectable in this PCR. To further confirm the specificity of the described mycoplasma PCR test, we used an additional 16 bacterial species [14], and all of them were not detected by this PCR (Table 3), confirming the high specificity of this method.

\subsection{Representative Data of Mycoplasma-Positive Cells in Laboratory Cultures}

To use this PCR test for laboratory management of contamination in cultured cells, we performed the test on many cell lines, including iPS-RPE cells. For each cell line, DNA was extracted and PCR was performed. The representative PCR data of mycoplasma-positive and -negative cells are shown in Figure 3A. The positive was a B cell line (B95-8).

When observed under an inverted microscope, the culture of the B95-8 B cell line that was mycoplasma-positive by PCR was indistinguishable from the one that was mycoplasma-negative by PCR (Figure 3B). By quantitative real-time PCR (qPCR), the infection of Mycoplasma spp. in these B95-8 cells was calculated as $4.4 \times 10^{6}$ copies $/ \mathrm{mL}$. One of the cultures of commercially available human RPE cell line (ARPE-19) was also positive, but was apparently indistinguishable from uninfected batch by observation under 
amicroscope (Figure 3C). The copy number of Mycoplasma spp. calculated by qPCR in these infected ARPE-19 cells was low $\left(9.3 \times 10^{2}\right.$ copies $\left./ \mu \mathrm{L}\right)$ but still detectable. Albeit detected by PCR, these two examples of infected cells show it was difficult to determine mycoplasma contamination by microscopic observation.

A

\begin{tabular}{|l|c|c|}
\hline Pathogen DNA & $\begin{array}{c}\text { Number of copies } \\
\text { (copies/ } \mu \mathrm{L} \text { ) }\end{array}$ & Results \\
\hline Bacteria 16S & $1.0 \times 10^{6}$ & negative \\
\cline { 2 - 3 } & $1.0 \times 10^{4}$ & negative \\
\cline { 2 - 3 } & $1.0 \times 10^{2}$ & negative \\
\hline Fungal 28S & $1.0 \times 10^{6}$ & negative \\
\cline { 2 - 3 } & $1.0 \times 10^{4}$ & negative \\
\cline { 2 - 3 } & $1.0 \times 10^{2}$ & negative \\
\hline Chlamydia & $1.0 \times 10^{6}$ & negative \\
\cline { 2 - 3 } & $1.0 \times 10^{4}$ & negative \\
\cline { 2 - 3 } & $1.0 \times 10^{2}$ & negative \\
\hline P. acnes & $1.0 \times 10^{6}$ & negative \\
\cline { 2 - 3 } & $1.0 \times 10^{4}$ & negative \\
\cline { 2 - 3 } & $1.0 \times 10^{2}$ & negative \\
\hline Syphilis & $1.0 \times 10^{6}$ & negative \\
\cline { 2 - 3 } & $1.0 \times 10^{4}$ & negative \\
\cline { 2 - 3 } & $1.0 \times 10^{2}$ & negative \\
\hline HSV-1 & $1.0 \times 10^{6}$ & negative \\
\cline { 2 - 3 } & $1.0 \times 10^{4}$ & negative \\
\cline { 2 - 3 } & $1.0 \times 10^{2}$ & negative \\
\hline
\end{tabular}

B

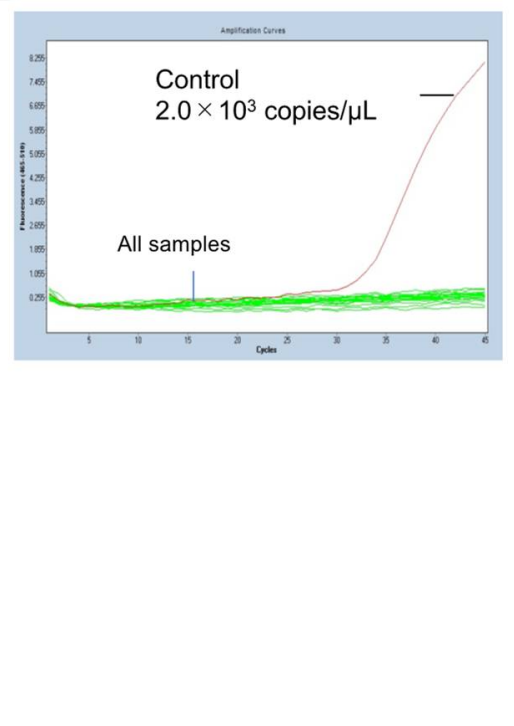

Figure 2. PCR results of mycoplasma specificity test. For this assay, synthetic DNA of bacterial species other than class Mollicutes, a fungus, and a virus were used: Bacterial 16S rDNA (Staphylococcus aureus 16S region), Fungal 28S rDNA (Cryptococcus 28S region), Chlamydia (Chlamydia pneumoniae 16S-23S spacer region), P. acnes rDNA (Propionibacterium acnes 16S region), Syphilis (Treponema pallidum TP47 gene region), and HSV-1 (Herpes simplex virus 1 UL27 gene region). (A) All of the examined DNA templates were undetectable. (B) The detection level against the number of PCR-cycles shows all tested DNA, including bacterial DNA templates, was undetectable; the copy number of the positive control mycoplasma DNA $\left(2 \times 10^{3}\right.$ copies $\left./ \mathrm{mL}\right)$ was calculated by qPCR.

Table 3. Detection of main causative bacterial agents of infectious endophthalmitis by Myco Finder PCR.

\begin{tabular}{|c|c|c|c|}
\hline Strains & Clone No. & $\begin{array}{l}\text { Number of Copies } \\
\text { (Copies/mL) }\end{array}$ & PCR Results \\
\hline \multicolumn{4}{|l|}{ Gram-positive strains } \\
\hline Staphylococcus aureus & NBRC12732 & $1.0 \times 10^{4}$ & negative \\
\hline MRSA & JCM8702 & $1.0 \times 10^{4}$ & negative \\
\hline Staphylococcus epidermidis & JCM2414 & $1.0 \times 10^{4}$ & negative \\
\hline Streptococcus pyogenes & RIMD 3123004 & $1.0 \times 10^{4}$ & negative \\
\hline Streptococcus sanguinis & JCM5708 & $1.0 \times 10^{4}$ & negative \\
\hline Streptococcus pneumoniae & NBRC102642 & $1.0 \times 10^{4}$ & negative \\
\hline Enterococcus faecalis & JCM20313 & $1.0 \times 10^{4}$ & negative \\
\hline Corynebacterium diphtheriae & JCM1310 & $1.0 \times 10^{4}$ & negative \\
\hline Bacillus cereus & JCM20266 & $1.0 \times 10^{4}$ & negative \\
\hline Clostridium perfringens & JCM1290 & $1.0 \times 10^{4}$ & negative \\
\hline Propionibacterium acnes & JCM6425 & $1.0 \times 10^{4}$ & negative \\
\hline Nocardia asteroides & NBRC14403 & $1.0 \times 10^{4}$ & negative \\
\hline \multicolumn{4}{|l|}{ Gram-negative strains } \\
\hline Escherichia coli & JCM20135 & $1.0 \times 10^{4}$ & negative \\
\hline Klebsiella pneumoniae & $\mathrm{JCM} 1662$ & $1.0 \times 10^{4}$ & negative \\
\hline Pseudomonas aeruginosa & JCM6425 & $1.0 \times 10^{4}$ & negative \\
\hline Moraxella lacunata & JCM20914 & $1.0 \times 10^{4}$ & negative \\
\hline
\end{tabular}

MRSA-Methicillin-resistant Staphylococcus aureus. 

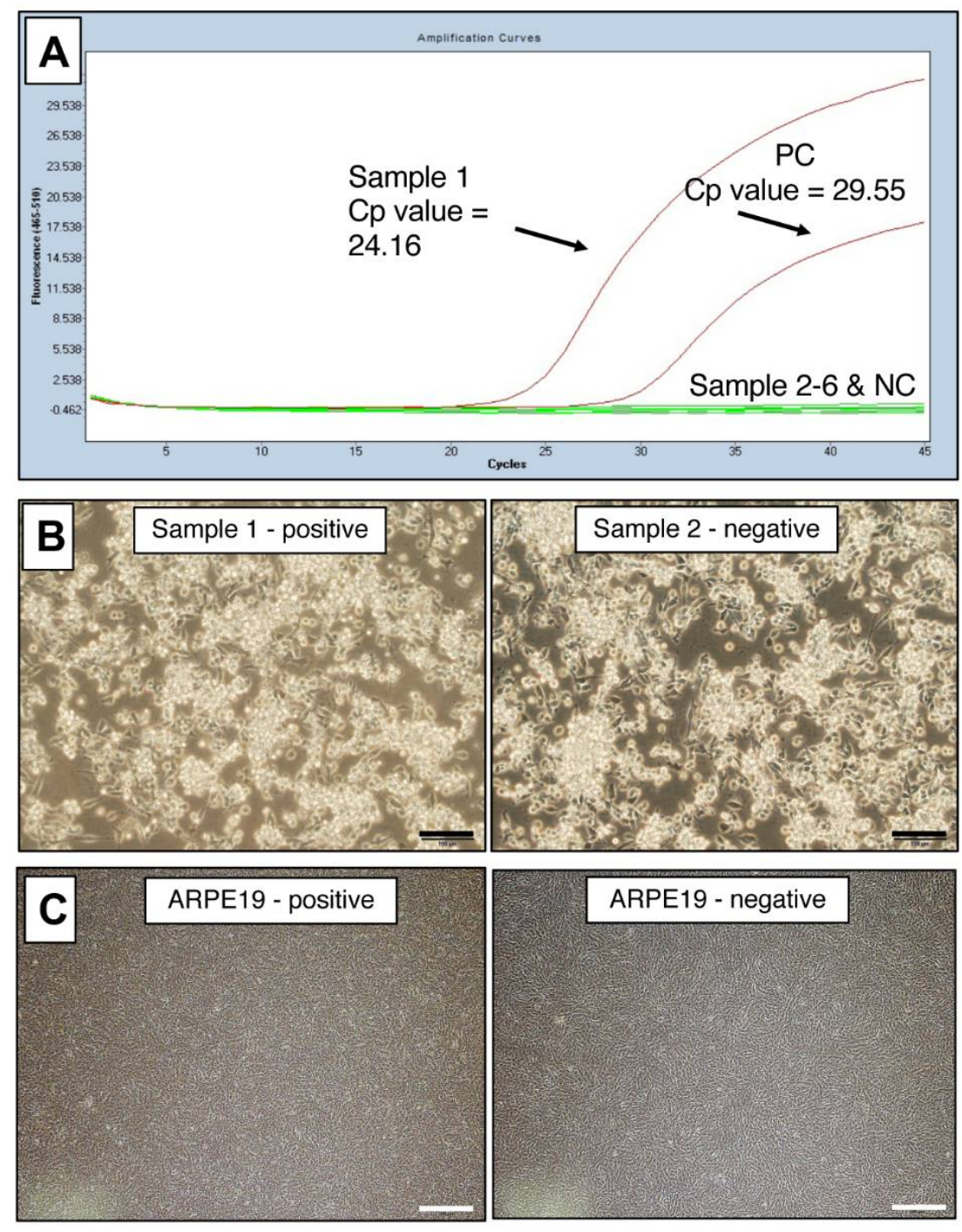

Figure 3. Representative PCR data of mycoplasma-positive cells. (A) Myco Finder PCR assay was performed on six cultures of three cell lines (B cell lines, iPS cells, and RPE cells) cultured in our laboratory. Sample 1 was positive, and Samples 2, 3, 4, 5, and 6 were negative. Cp value: crossing point value. (B) Positive and negative cultures of B95-8 B cell line were indistinguishable by observation under an inverted microscope: left (sample 1) was mycoplasma-positive, and right (Sample 2) was mycoplasma-negative by Myco Finder PCR. Scale bars: $100 \mu \mathrm{m}$. (C) Positive and negative cultures of a human RPE cell line (ARPE-19 cell line) were indistinguishable by the observation under an inverted microscope: left was mycoplasma-positive, and right was mycoplasma-negative by Myco Finder PCR. Scale bars: $500 \mu \mathrm{m}$.

With this PCR test, we confirmed that the iPS cells $(n=8)$ and iPS-RPE cells $(n=29)$ established in our laboratory were all negative. Primary RPE cells were also all negative $(\mathrm{n}=4)$, but the ARPE-19 cell line was positive in one of the three cultures. B cell line (B95-8) was positive in one of the eight cultures. These results back up the notion that long-term cultured cells, such as cell lines, have increased risk of infection by class Mollicutes-bacteria, thus requiring extra attention.

\subsection{Detection of Mycoplasma by SEM}

We next examined the infected cells using scanning electron microscope (SEM) for the detection of mycoplasma. We harvested two cultured monkey iPS-RPE cells (line 46a) that were mycoplasma DNA-positive or -negative by Myco Finder PCR and observed them under SEM, which showed proliferating mycoplasma-like circular particles on infected 
RPE cells. While microvilli were observed on the cell surface of our established iPS-RPE cells under SEM (Figure 4A), we failed to find any microvilli on the cell surface of infected cells from six images of SEM (Figure 4B). In the magnified image of X30,000 (Figure 4B'), a large number of circular particles that seem to be mycoplasma with high electron density were observed. In contrast, no such particles were found in the control RPE cells that were mycoplasma-negative by Myco Finder PCR. From the entire view of one SEM image, we could see the infected cells were smaller overall compared to non-infected cells (Figure 4C). For evaluation of the size of infected and non-infected cells, as RPE cells were often larger than the field of view, instead of measuring the cell size, we counted the cell number in one field of view. The criteria for counting one cell were to have the nucleus in the field of view, without counting debris with obviously broken morphology (Figure 4D). As a result, the cell numbers of mycoplasma-positive cells were significantly higher than those of mycoplasma-negative cells, suggesting mycoplasma-infected cells had become smaller and lost RPE-specific cell morphology. By observing single units of mycoplasma under electron microscope, it was confirmed by PCR that mycoplasma-positive cells were indeed infected.

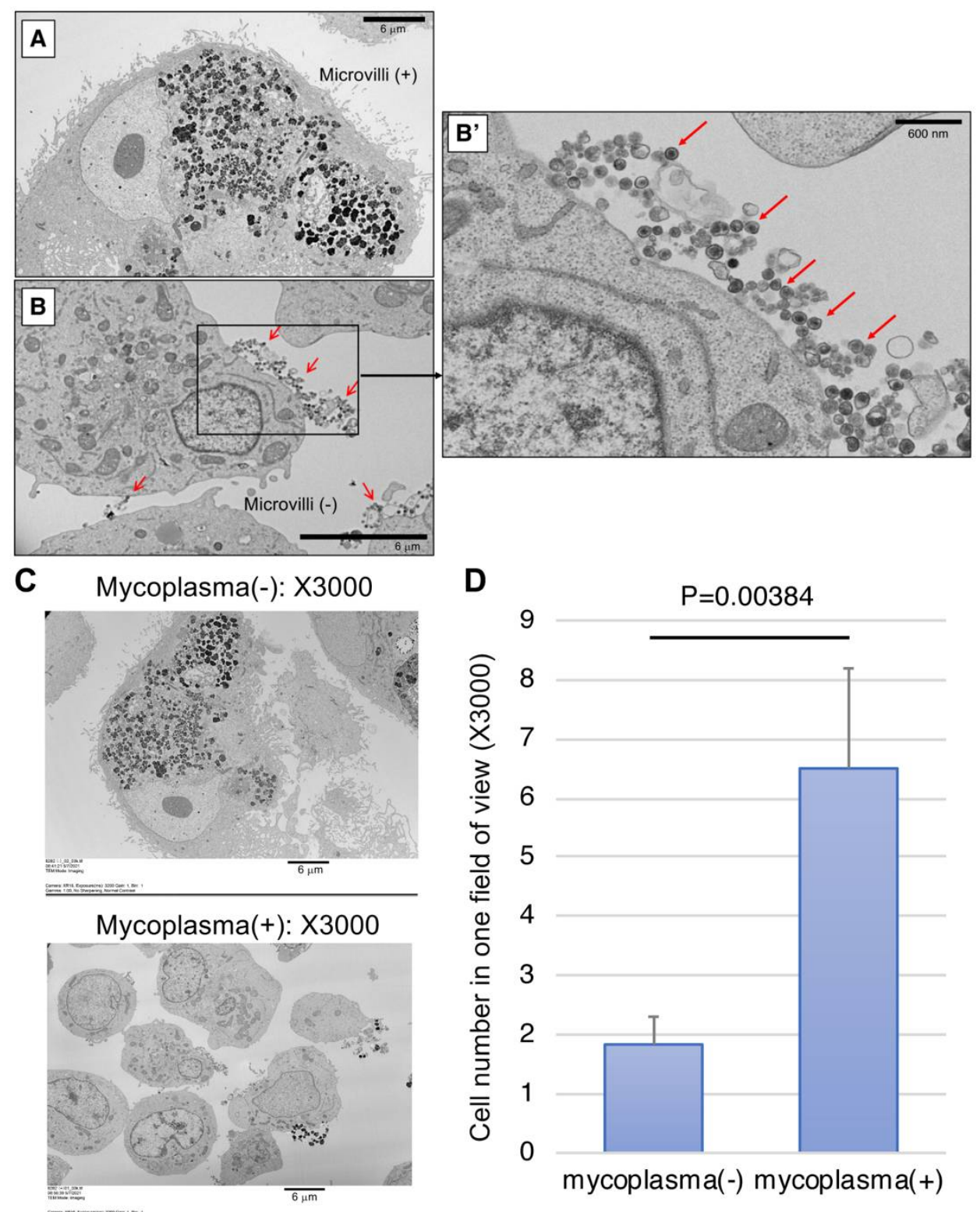

Figure 4. Representative pictures of scanning electron microscope (SEM) of mycoplasma-positive and 
-negative iPS-RPE cells. (A) Control iPS-RPE cells (mycoplasma-negative). Scale bar: $6 \mu \mathrm{m}$. (B) Mycoplasma-positive iPS-RPE cells. Scale bar: $6 \mu \mathrm{m}$. (B') Magnified image (X30,000) of a mycoplasmapositive cell. Red arrows: high-density circular particles (=mycoplasma) detected under SEM. Scale bar: $600 \mathrm{~nm}$. (C) The entire view of one SEM image (X3000). Upper: mycoplasma-positive RPE cells, lower: mycoplasma-negative RPE cells. (D) Cell numbers of mycoplasma-positive and -negative cells in one field of view (X3000). Cells with their nuclei in the view were counted, not counting debris with obviously broken morphology. The bar graph shows the average of six views with standard deviation $P=0.00384$ between two groups ( $t$-test; $\mathrm{n}=6$ for each group).

\section{Discussion}

We analyzed mycoplasma contamination in transplantable iPSC-derived RPE cells by rapid PCR examination. The results of PCR were negative in the iPS cells and iPS-RPE cells established in our laboratory but were positive in some of the cultures of commercially available cell lines. In the spike tests of nine bacterial species of class Mollicutes in RPE cells, $100 \mathrm{CFU} / \mathrm{mL}$ and $10 \mathrm{CFU} / \mathrm{mL}$ of spiked Mollicutes DNA were detected with $100 \%$ probability in all cases, and $1 \mathrm{CFU} / \mathrm{mL}$ had a detection rate of $0-75 \%$. Additionally, bacterial DNA other than from class Mollicutes species was not detected by this PCR, indicating the test was not only sensitive but also highly specific.

Table 4 summarizes the comparison between the conventional tests for detecting mycoplasma contamination and Myco Finder PCR test. The conventional tests in Japan, which comply with the 16th revision of the Japanese Pharmacopoeia, are DNA staining and nested PCR. Real-time quantitative PCR is now also used [15]. These tests are often complicated and require experienced technicians. In addition, the sensitivity of DNA staining and nested PCR is $100 \mathrm{CFU} / \mathrm{mL}$, and the average testing time for DNA staining is around 6 days. In contrast, Myco Finder PCR test, which complies with the 17th revision of the Japanese Pharmacopoeia, is semi-quantitative and not complicated. Importantly, its sensitivity is as high as $10 \mathrm{CFU} / \mathrm{mL}$, and the testing time is around $140 \mathrm{~min}$ (Table 4). In fact, for the clinical study of RPE transplantation, conventional tests (DNA staining and nested PCR) were performed two weeks before the operation, and Myco Finder PCR test was additionally conducted on the day of transplantation [2]. This allowed for the monitoring of the latest condition of the cells immediately before the transplantation, according to which decisions to discontinue the operation could be made in case infection was detected.

Table 4. Comparing Myco Finder PCR test with conventional methods for detecting mycoplasma.

\begin{tabular}{ccccc}
\hline & Myco Finder PCR & DNA Staining & Nested PCR & Real-Time PCR ** \\
\hline Method & Semi-quantitative PCR & Staining & Qualitative PCR & Quantitative PCR \\
Testing & Simplified & Experienced & Experienced & Experienced \\
Specimens & Cells $\left(\leq 1 \times 10^{6}\right)$ & Culture supernatant & Culture supernatant & Cells $\left(\leq 5 \times 10^{6}\right)$ \\
Sensitivity & $10 \mathrm{CFU} / \mathrm{mL}$ & $100 \mathrm{CFU} / \mathrm{mL}$ & $100 \mathrm{CFU} / \mathrm{mL}$ & $10 \mathrm{CFU} / \mathrm{mL}$ \\
Testing time & $140 \mathrm{~min}$ & 6 days & $6 \mathrm{~h}$ & $4 \sim 5 \mathrm{~h}$ \\
JapanesePharmacopoeia & 17 th revision & 16th revision & 16th revision & $17 \mathrm{th}$ revision \\
\hline
\end{tabular}

Conventional methods indicate our previous conventional tests for detecting Mycoplasma spp. ${ }^{*}$ Testing time-time from specimen submission until determination of the result. ${ }^{* *}$ Real-time PCR for detecting Mycoplasma spp.

Mycoplasma contamination has high prevalence, with more than $20 \%$ of cell cultures infected [5], suggesting mycoplasma potentially has higher risk of infection than other bacteria, fungi, and viruses. Among the class Mollicutes bacteria, $M$. arginini, M. fermentans, M. hominis, M. hyorhinis, M. orale, and Acholeplasma laidlawii account for the majority of the infections [6]. Since mycoplasma infections are usually unrecognizable or invisible by observation under a microscope during routine cell culture, they are risk factors for cell-based transplantation. The conventional methods currently conducted for detection are DNA staining, single-based PCR (PCR for one target gene), nested PCR, ELISA, qPCR, and fluorescent in situ hybridization (FISH) [7-13]. However, as these tests are time-consuming, it is not realistic to perform the tests every time we find suspicious cultures. 
We herein report a rapid detection test for class Mollicutes bacterial species that can be easily performed in the laboratory. This PCR assay is based on the hybridization of an oligonucleotide probe that binds to a sequence within the 16S ribosomal RNA (i.e., 16S rDNA) of mycoplasma, which, together with the PCR primers, specifically amplifies the DNA sequence coding the mycoplasma rRNA gene. Theoretically, all Mycoplasma spp.which includes more than 200 species-can be identified using these primers and probe. Hybridization to abundantly present ribosomal RNA provides a highly sensitive method that is readily applicable for mandatory quality-control tests in cell-based transplantation.

We have previously reported the incidence of mycoplasma infection in the eye of a monkey after subretinal transplantation of iPS-derived RPE cells [15]. Ophthalmological examination showed mass lesions and retinal vasculitis in the subretina, and pathological examination demonstrated severe infiltration of inflammatory cells at the transplantation site (RPE grafts) and hematoma in the retina and the subretina. By immunohistochemistry, infiltrations of diverse inflammatory cells, including T/B lymphocytes, neutrophils, and NK cells, were observed in the grafted area, the retina, and the choroids in the eye [15]. The acute and severe intraocular inflammation in this monkey after the transplantation warned us that the administration of mycoplasma-infected cells could be very dangerous. In fact, animal models with direct injection of mycoplasma into the eye exhibit similar ocular inflammation [16,17], and there are several reports of human uveitis with mycoplasma infections [18-20]. More importantly, while the ocular findings caused by the rejection after RPE cell transplantation with allografts [21-25] and those caused by mycoplasma infection are similar, especially in the early stages. However, the treatments for these two types of intraocular inflammation are completely different, making it necessary to have a sensitive method for mycoplasma detection at early stage of infection. Altogether, mycoplasma could cause inflammation when entered into the eye, and the need for regular and rapid mycoplasma testing of graft cells/tissues before and after transplantation into the retina was reaffirmed.

\section{Materials and Methods}

\subsection{Cells and DNA Extraction}

Human iPS cells, human RPE cell lines (ARPE-19), B cell lines (B95-8), and human Ff-I iPS cell-derived RPE cell lines were used. Additionally, human iPS cell-derived RPE cells were established, as described previously [26,27], from the iPS cell line that was used in a previous clinical study (line QHJI01s04) [2]. For Myco Finder PCR assay, $5 \times 10^{5}$ cells of each cell line were harvested in sterile PBS, followed by DNA extraction with an automatic extraction machine (Qiagen, Valencia, CA, USA) and a DNA extraction kit (QIAamp UCP DNA Micro Kit: Qiagen).

For spike tests, $1.6 \times 10^{7} \mathrm{RPE}$ cells derived from human Ff-I iPS cells were prepared in PBS. Then, each mycoplasma strain diluted in PBS was added at the final concentration of 100,10 , and $1 \mathrm{CFU} / \mathrm{mL}$, followed by heat treatment with proteinase $\mathrm{K}$ and DNA extraction by an automatic extraction machine and DNA extraction kit (Qiagen).

The cultured cell lines were also observed under an inverted microscope (IX71, OLYMPUS, Tokyo, Japan).

\subsection{Mycoplasma Strains}

Seven strains of Mycoplasma spp. listed in the 17th revision of the Japanese Pharmacopoeia were used: M. hyorhinis, M. pneumoniae, M. orale, M. fermentans, M. salivarium, M. hominis, and M. arginini. We also prepared two more species from different genera of class Mollicutes, A. laidlawii and U. urealyticum. The strains were purchased from the American Type Culture Collection (ATCC) and the NITE Biological Resource Center (NBRC) (Table 1). 


\subsection{CFU and GC Measurements}

Genomic copy (GC)/ colony-forming units (CFU) ratios were measured by National Institute of Health Sciences (NIHS) -based methods $(n=3)$. For CFU measurements, mycoplasma stocks stored at $-80{ }^{\circ} \mathrm{C}$ were thawed, and a 10-fold dilution series up to $10^{-7}$ was prepared in liquid medium (Hayflick Liquid: Merck Millipore, Tokyo, Japan). One of the Mycoplasma spp. M. pneumoniae was shredded by passing through a 27G needle syringe (Terumo, Tokyo, Japan) 10 times before dilution. Other Mycoplasma spp. were diluted immediately after thawed. Five $\mu \mathrm{L}$ of each mycoplasma diluted solution was added dropwise to Hayflick agar (Merck Millipore) at two locations and cultured at $37^{\circ} \mathrm{C}$ in aerobic culture (AnaeroPack $\mathrm{CO}_{2}$ ) for A. laidlawii, M. arginine, M. hominis, M. hyorhinis, M. pneumoniae, or U. urealyticum and in anaerobic culture (AnaeroPack Kenki) for M. orale, M. fermentans, and M. salivarium. Then, the number of mycoplasma colonies was counted under the microscope (inverted microscope: NIKON Eclipse TI-HUBC, Tokyo, Japan), and $\mathrm{CFU} / \mathrm{mL}$ was calculated. For GC measurements, mycoplasma solution was centrifuged $\left(14,000 \times g, 4{ }^{\circ} \mathrm{C}, 30 \mathrm{~min}\right)$, and DNA was extracted from the pellets using the PureLink Genomic DNA Mini Kit (Life Technologies). The DNA content measured by optical density at $260 \mathrm{~nm}$ (NanoDrop 1000, Thremo Scientific, Waltham, MA, USA) was used to calculate the genome copy number with the following formula [28]:

$$
\text { Copies } / \mathrm{mL}=[\mathrm{DNA} \text { contents }(\mu \mathrm{g} / \mathrm{mL})] \times 10^{6} \times\left(0.978 \times 10^{9}\right) / \text { [genome size] }
$$

The average of three independent measurements was used for CFU and GC measurements, respectively.

\section{4. $P C R$}

PCR was performed using the Myco Finder Kit (Nissui Pharmaceutical Co., Ltd., Tokyo, Japan) and LightCycler 480 II instrument (Roche, Basel, Switzerland) with the conditions shown in Figure 5. In the spike tests, each of the nine strains (refer to Table 1) was added to iPS-RPE cells at the concentrations of 1,10 , and $100 \mathrm{CFU} / \mathrm{mL}$, respectively, for sensitivity evaluation. To confirm the data, quantitative real-time PCR (qPCR) was performed with a set of primers and probe targeting the 16S rDNA of mycoplasma (Nihon Techno Service Co., Ltd.; Tokyo, Japan), as described previously [15]. Prior to spike tests, the cell culture used for the test was verified as "mycoplasma negative" by the above-described qPCR targeting the $16 \mathrm{~S}$ rDNA.

PCR conditions
\begin{tabular}{|c|c|c|}
\hline temperature & time & cycles \\
\hline $95^{\circ} \mathrm{C}$ & $10 \mathrm{sec}$ & 1 \\
\hline $98^{\circ} \mathrm{C}$ & $3 \mathrm{sec}$ & 45 \\
\hline $60^{\circ} \mathrm{C}$ & $15 \mathrm{sec}$ & 45 \\
\hline
\end{tabular}
Petection Channels: FAM $(510 \mathrm{~nm})$ and HEX $(580 \mathrm{~nm})$
PCR system : Light Cycler $480 \mathrm{II}$ (Roche diagnostics)

Figure 5. PCR Conditions for Myco Finder Kit. Samples were prepared in 8-well microtubes (right), and the DNA was amplified with LightCycler 480 II under the condition shown (left).

For specificity evaluation, Myco Finder PCR was tested on whole or synthetic DNA of 22 pathogens, including 20 bacteria other than class Mollicutes, a fungus, and a virus: Bacterial 16S rDNA (Staphylococcus aureus 16S region), P. acnes rDNA (Propionibacterium acnes $16 \mathrm{~S}$ region), Chlamydia (Chlamydia pneumoniae 16S-23S spacer region), Syphilis (Treponema pallidum TP47 gene region), Fungal $28 \mathrm{~S}$ rDNA (Cryptococcus $28 \mathrm{~S}$ region), and HSV-1 (Herpes simplex virus 1 UL27 gene region). These synthetic DNA products were purchased from 
Nihon Techno Service Co., Ltd. The result was similar to the specificity data provided by the vendor of Myco Finder PCR on their website (Nissui pharmaceuticals; https: / / www. nissui-pharm.co.jp/english/pdf/products/global/Pharmacopoeia_Validation.pdf). In addition, 16 bacteria (other than class Mollicutes) in Table 3 were tested on whole DNA, as described in our previous report [14].

\subsection{Scanning Electron Microscope}

For the detection of mycoplasma, we examined mycoplasma-infected retinal cells by scanning electron microscope (SEM). We harvested two cultured monkey iPS-RPE cells (line 46a) that were mycoplasma DNA-positive or -negative by Myco Finder PCR. 46a monkey iPS-RPE cells were previously established in our lab [21]. SEM observation was performed by Hanaichi UltraStructure Research Institute, Co., Ltd. (Aichi, Japan) with a HITACHI H-7600 (Hitachi High-Tech Co., Tokyo, Japan) electron microscope. For evaluation of the cell size, the cell number observable in one view was counted in 6 views of each culture. The criteria of counting one cell were to have the nucleus in the field, not counting debris with obviously broken morphology. The average of six views with standard deviation was used for quantification. For statistical analysis, $t$-test was used.

\section{Conclusions}

The Myco Finder Kit, a rapid and simple PCR system, had high sensitivity and specificity to detect class Mollicutes species such as M. hyorhinis, M. pneumoniae, M. orale, M. fermentans, M. salivarium, M. hominis, M. arginine, A. laidlawii, and U. urealyticum, which was applicable for the detection of mycoplasma infection in transplantable RPE cells. This method is worth evaluating in clinical trials/studies for the detection of mycoplasma in transplants.

Author Contributions: S.S. and M.T. designed the study. S.S. performed the in vitro experiments. A.H., S.F. and Y.Y. conducted the PCR analysis. S.S., Y.Y. and N.S. analyzed the data. S.S. wrote the manuscript. Y.F. revised manuscript. All authors reviewed the manuscript. All authors have read and agreed to the published version of the manuscript.

Funding: This work was supported by the Research Center Network for Realization of Regenerative Medicine of the Japan Agency for Medical Research and Development (AMED: JP20bm0204002).

Institutional Review Board Statement: This study was approved by the Institutional Ethics Committee of the Riken BDR (Approval No. KOBE-IRB-16-36, 6 January 2016).

Informed Consent Statement: Not applicable.

Acknowledgments: We thank N. Hayashi and K. Iseki (Laboratory for Retinal Regeneration, RIKEN Center for Biosystems Dynamics Research, Kobe, Japan), as well as K. Watanabe (Tokyo Medical and Dental University), for their expert technical assistance.

Conflicts of Interest: Y.Y. is employed by Nissui Pharmaceutical Corporation. Other authors declare no conflicts of interest.
Abbreviations
CFU colony-forming unit
$\mathrm{Cp} \quad$ crossing point
GC genomic copy
iPSC induced pluripotent stem cells
PCR polymerase chain reaction
qPCR quantitative real-time PCR
RPE retinal pigment epithelium
rDNA ribosomal DNA
SEM scanning electron microscope 


\section{References}

1. Mandai, M.; Watanabe, A.; Kurimoto, Y.; Hirami, Y.; Morinaga, C.; Daimon, T.; Fujihara, M.; Akimaru, H.; Sakai, N.; Shibata, Y.; et al. Autologous Induced Stem-Cell-Derived Retinal Cells for Macular Degeneration. N. Engl. J. Med. 2017, 376, 1038-1046. [CrossRef]

2. Sugita, S.; Mandai, M.; Hirami, Y.; Takagi, S.; Maeda, T.; Fujihara, M.; Matsuzaki, M.; Yamamoto, M.; Iseki, K.; Hayashi, N.; et al. HLA-Matched Allogeneic iPS Cells-Derived RPE Transplantation for Macular Degeneration. J. Clin. Med. 2020, 9, 2217. [CrossRef] [PubMed]

3. Teyssou, R.; Poutiers, F.; Saillard, C.; Grau, O.; Laigret, F.; Bové, J.M.; Bébéar, C. Detection of mollicute contamination in cell cultures by $16 \mathrm{~S}$ rDNA amplification. Mol. Cell Probes 1993, 7, 209-216. [CrossRef]

4. Uphoff, C.C.; Drexler, H.G. Comparative PCR analysis for detection of mycoplasma infections in continuous cell lines. In Vitro Cell Dev. Biol. Anim. 2002, 38, 79-85. [CrossRef]

5. Drexler, H.G.; Uphoff, C.C. Mycoplasma contamination of cell cultures: Incidence, sources, effects, detection, elimination, prevention. Cytotechnology 2002, 39, 75-90. [CrossRef]

6. Kong, F.; James, G.; Gordon, S.; Zelynski, A.; Gilbert, G.L. Species-specific PCR for identification of common contaminant mollicutes in cell culture. Appl. Environ. Microbiol. 2001, 67, 3195-3200. [CrossRef]

7. Van Kuppeveld, F.J.; Johansson, K.E.; Galama, J.M.; Kissing, J.; Bölske, G.; van der Logt, J.T.; Melchers, W.J. Detection of mycoplasma contamination in cell cultures by a mycoplasma group-specific PCR. Appl. Environ. Microbiol. 1994, 60, 149-152. [CrossRef] [PubMed]

8. Uphoff, C.C.; Drexler, H.G. Detection of mycoplasma contaminations in cell cultures by PCR analysis. Hum. Cell 1999, 12, 229-236.

9. Uphoff, C.C.; Drexler, H.G. Detection of Mycoplasma contamination in cell cultures. Curr. Protoc. Mol. Biol. 2014, 106, 28.4.1-28.4.14. [CrossRef] [PubMed]

10. Young, L.; Sung, J.; Stacey, G.; Masters, J.R. Detection of Mycoplasma in cell cultures. Nat. Protoc. 2010, 5, 929-934. [CrossRef] [PubMed]

11. Salling, H.K.; Bang-Christensen, S.R. Multi-primer qPCR assay capable of highly efficient and specific detection of the vast majority of all known Mycoplasma. Biologicals 2016, 44, 129-138. [CrossRef]

12. Shahhosseiny, M.H.; Hosseiny, Z.; Khoramkhorshid, H.R.; Azari, S.; Shokrgozar, M.A. Rapid and sensitive detection of Mollicutes in cell culture by polymerase chain reaction. J. Basic Microbiol. 2010, 50, 171-178. [CrossRef]

13. Jean, A.; Tardy, F.; Allatif, O.; Grosjean, I.; Blanquier, B.; Gerlier, D. Assessing mycoplasma contamination of cell cultures by qPCR using a set of universal primer pairs targeting a $1.5 \mathrm{~kb}$ fragment of 16S rRNA genes. PLoS ONE 2017, 12, e0172358. [CrossRef]

14. Ogawa, M.; Sugita, S.; Shimizu, N.; Watanabe, K.; Nakagawa, I.; Mochizuki, M. Broad-range real-time PCR assay for detection of bacterial DNA in ocular samples from infectious endophthalmitis. Jpn J. Ophthalmol. 2012, 56, 529-535. [CrossRef]

15. Makabe, K.; Sugita, S.; Hono, A.; Kamao, H.; Takahashi, M. Mycoplasma Ocular Infection in Subretinal Graft Transplantation of iPS Cells-Derived Retinal Pigment Epithelial Cells. Investig. Ophthalmol. Vis. Sci. 2019, 60, 1298-1308. [CrossRef] [PubMed]

16. Pavan-Langston, D. Mycoplasmal anterior and posterior uveitis. I. Clinical manifestations of the experimental disease. Arch. Ophthalmol. 1969, 82, 245-252. [CrossRef] [PubMed]

17. Pavan-Langston, D., II. Histopathologic manifestations of mycoplasmal uveitis. Arch. Ophthalmol. 1969, 82, 253-258. [PubMed]

18. Liu, E.M.; Janigian, R.H. Mycoplasma pneumoniae: The other masquerader. JAMA Ophthalmol. 2013, 131, 251-253. [CrossRef]

19. Matsou, A.; Riga, P.; Samouilidou, M.; Dimitrakos, S.; Anastasopoulos, E. Bilateral intermediate uveitis with appearance of frosted branch angiitis and association with Mycoplasma pneumoniae infection: Case report and review of the literature. J. AAPOS 2016, 20, 358-361. [CrossRef]

20. Yashar, S.S.; Yashar, B.; Epstein, E.; Viani, R.M. Uveitis associated with Mycoplasma pneumoniae meningitis. Acta Ophthalmol. Scand. 2001, 79, 100-101. [CrossRef]

21. Sugita, S.; Iwasaki, Y.; Makabe, K.; Kamao, H.; Mandai, M.; Shiina, T.; Ogasawara, K.; Hirami, Y.; Kurimoto, Y.; Takahashi, M. Successful Transplantation of Retinal Pigment Epithelial Cells from MHC Homozygote iPSCs in MHC-Matched Models. Stem Cell Rep. 2016, 7, 635-648. [CrossRef] [PubMed]

22. Sugita, S.; Makabe, K.; Fujii, S.; Iwasaki, Y.; Kamao, H.; Shiina, T.; Ogasawara, K.; Takahashi, M. Detection of Retinal Pigment Epithelium-Specific Antibody in iPSC-Derived Retinal Pigment Epithelium Transplantation Models. Stem Cell Rep. 2017, 9, 1501-1515. [CrossRef] [PubMed]

23. Fujii, S.; Sugita, S.; Futatsugi, Y.; Ishida, M.; Edo, A.; Makabe, K.; Kamao, H.; Iwasaki, Y.; Sakaguchi, H.; Hirami, Y.; et al. A Strategy for Personalized Treatment of iPS-Retinal Immune Rejections Assessed in Cynomolgus Monkey Models. Int. J. Mol. Sci. 2020, 21, 3077. [CrossRef]

24. Sugita, S.; Futatsugi, Y.; Ishida, M.; Edo, A.; Takahashi, M. Retinal Pigment Epithelial Cells Derived from Induced Pluripotent Stem (iPS) Cells Suppress or Activate T Cells via Costimulatory Signals. Int. J. Mol. Sci. 2020, 21, 6507. [CrossRef] [PubMed]

25. Sugita, S.; Mandai, M.; Kamao, H.; Takahashi, M. Immunological aspects of RPE cell transplantation. Prog. Retin. Eye Res. 2021, 84, 100950. [CrossRef]

26. Sugita, S.; Kamao, H.; Iwasaki, Y.; Okamoto, S.; Hashiguchi, T.; Iseki, K.; Hayashi, N.; Mandai, M.; Takahashi, M. Inhibition of T-cell activation by retinal pigment epithelial cells derived from induced pluripotent stem cells. Investig. Ophthalmol. Vis. Sci. 2015, 56, 1051-1062. [CrossRef] [PubMed] 
27. Sugita, S.; Iwasaki, Y.; Makabe, K.; Kimura, T.; Futagami, T.; Suegami, S.; Takahashi, M. Lack of T Cell Response to iPSC-Derived Retinal Pigment Epithelial Cells from HLA Homozygous Donors. Stem Cell Rep. 2016, 7, 619-634. [CrossRef] [PubMed]

28. Dolezel, J.; Bartos, J.; Voglmayr, H.; Greilhuber, J. Nuclear DNA content and genome size of trout and human. Cytom. A 2003, 51, 127-128. 